PRZEMYSŁAW ŚLESZYŃSKI

Polska Akademia Nauk

Warszawa

\title{
Powiązania organizacyjne i właścicielskie przedsiębiorstw przemysłowych i usługowych w Polsce oraz ich znaczenie dla rozwoju regionalnego
}

\section{WPROWADZENIE}

Powiązania gospodarcze we współczesnym świecie stają się coraz bardziej różnorodne i skomplikowane. Wynika to z faktu, że cechą charakterystyczną systemów ekonomicznych jest permanentna nierównowaga przestrzenna, polegająca na tendencji do dywergencji, czyli wzrostu zróżnicowań przestrzennych (polaryzacji przestrzennej). Przyczyną tego są z kolei takie czynniki, jak wzrost wielkości przedsiębiorstw w sferze ekonomicznej, zwiększanie ich przestrzennego zasięgu oddziaływania, rosnące zróżnicowanie działalności i wreszcie wzrost komplikacji organizacyjnej. W konsekwencji organizacja przestrzenna systemów powiązań pomiędzy przedsiębiorstwami bardziej przypomina model sieciowy lub sieciowo-hierarchiczny, o skomplikowanych relacjach pomiędzy poszczególnymi elementami, niż dominujący $\mathrm{w}$ ubiegłym wieku model hierarchiczny o przejrzystej strukturze podległości i zależności.

Z punktu widzenia powiązań własnościowych i, szerzej, lokalizacji gospodarczych funkcji kontrolnych, wymienione wyżej tendencje komplikacyjne i polaryzacyjne mogą mieć różnorakie znaczenie. Dotyczyć to może koncentracji lub dekoncentracji przestrzennej lokalizacji zarządów, charakteru i organizacji powiązań organizacyjnych i kapitałowych itd. Aby to dokładniej objaśnić, konieczne jest przyjmowanie szeregu uproszczeń. Równocześnie powiązania gospodarcze są trudnym przedmiotem badań ze względu na brak lub szczątkowość danych statystycznych. Wynika to z jednej strony z uwarunkowań prawnych, takich jak tajemnica handlowa i statystyczna, a z drugiej - z olbrzymiej kosztochłonności rejestracji wielu zjawisk, np. przepływów w sieciach transportowych. W ostatnich latach w dyskusjach naukowych i naukowo-praktycznych podkreśla się zdecydowanie, że rozpoznanie struktury gospodarczej i społeczno-gospodarczej nie jest możliwe bez wyczerpujących analiz powiązań. Przykładowo w debacie na temat spójności terytorialnej na kontynencie europejskim (i nie tylko) modne stało się pojęcie „geografii przepływów” (nawiasem mówiąc, w naukach geograficznych wprowadzone już w latach 60. ubiegłego wieku przez W.L. Garrisona, w jego trzyczęściowej pracy z lat 1959-1960).

Dwie dekady intensywnych przekształceń polskiego systemu gospodarczego sprawiły, że został on „wprzęgnięty” w sieć światowych powiązań, zależności, stref wpływów, od- 
działywań itd. Jedną z takich kategorii są powiązania właścicielskie, polegające w istocie na możliwości rozporządzania majątkiem i pozycją przedsiębiorstwa. Chociaż z natury są one bardzo skomplikowane, ze względu na swój charakter należą do najbardziej trwałych.

W warunkach polskich, podobnie jak w innych krajach, badanie powiązań właścicielskich i organizacyjnych przedsiębiorstw jest zadaniem rzadko podejmowanym, gdyż wymaga żmudnego zgromadzenia wyczerpującej i wiarygodnej bazy. Taką bazę przygotowano w ramach dwóch grantów resortu nauki, realizowanych w Instytucie Geografii i Przestrzennego Zagospodarowania w latach 2004-2007 (projekt zakończony) oraz 2008-2010 (projekt realizowany) i na podstawie tych baz przygotowano niniejszy artykuł.

Baza powiązań organizacyjnych obejmuje wykaz oddziałów I rzędu dla 2000 największych podmiotów gospodarczych, bez sektora finansowego. Wykorzystano dane Hoppenstedt Bonnier, uzupełniane na podstawie indywidualnych informacji. Oddziały I rzędu obejmują przy tym filie, punkty handlowe, ekspozytury, delegatury, biura handlowe, ośrodki, zakłady, okręgi, przedstawicielstwa, „zwykłe” oddziały itd. Jako ciekawostkę można podać, że kwestia nazewnictwa była sprawą niezwykle indywidualną, bowiem zidentyfikowano około 200 unikalnych nazw jednostek organizacyjnych, bezpośrednio podległych centrali. Uzyskano informacje o 11,7 tys. oddziałów. Dane są aktualne na 2007 rok. Wyniki tych badań nie były jeszcze publikowane, a materiał przedstawiony w niniejszym artykule należy traktować jako wstępny.

Baza powiązań wlaścicielskich obejmuje wykaz podmiotów, które posiadały udziały akcyjne w 1242 największych pod względem przychodów z całokształtu działalności spółkach prawa handlowego w roku 2004. Dotyczyło to przedsiębiorstw osiagających obroty co najmniej $150 \mathrm{mln}$ zł i cezura ta była arbitralna. Przedsiębiorstwa te osiagnęły przychody w wysokości 1241 mld zł, co stanowi ponad 90,5\% przychodów wszystkich przedsiębiorstw w Polsce. Następnie dla tych podmiotów ustalono siedziby akcjonariuszy, proporcjonalnie do 71,5\% przychodów przedsiębiorstw. Pozostałą część stanowił akcjonariat nieustalony oraz osób fizycznych, w tym pracowników. Można zatem dalej obliczać, że uzyskano 54\% reprezentatywności właścicielskiej. Do ustalenia powiązań właścicielskich wykorzystano głównie dane ze wspomnianej bazy Hoppenstedt Bonnier, uzupełniane danymi uzyskanymi bezpośrednio z przedsiębiorstw, głównie na podstawie ich raportów rocznych oraz danych z oficjalnych stron internetowych. Dane są aktualne na 2004/2005 rok. Wyniki badań przedstawiano w kilku miejscach, najpełniej w pracach autora z 2007 r. i 2008 r.

\section{STRUKTURA ORGANIZACYJNA}

W 2007 roku pogłębiała się hipertrofia Warszawy w zakresie lokalizacji gospodarczych funkcji kontrolnych. Spośród 2000 największych polskich przedsiębiorstw aż 513 (ponad 1/4) swe główne polskie siedziby posiadało w granicach administracyjnych stolicy, a kolejne 58 - w jej strefie podmiejskiej. Następne w kolejności były: Kraków (83), Poznań (63), Wrocław (59) i Katowice (56, ale gdyby brać pod uwagę wszystkie miasta konurbacji śląskiej, to liczba ta wzrosłaby do ponad 140). Tymczasem w 2004 r. w stolicy były zlokalizowane 503 podmioty spośród największych 2 tys. Ze względu na fakt, że występuje prawidłowość polegająca na koncentracji największych przedsiębiorstw na wyższych szczeblach administracyjno-osadniczych, hipertrofia ta jest jeszcze bardziej wyraźna, jeśli weźmie się pod uwagę przychody z działalności. 
W porównaniu do koncentracji central, rozkład przestrzenny oddziałów I rzędu w bardziej zdecydowany sposób nawiązuje do struktury osadniczej (ryc. 1, ryc. 2). Okazuje się, że liczba tych oddziałów jest pochodną liczby ludności i da się ją aproksymować z dużym prawdopodobieństwem na podstawie funkcji matematycznych. Z obserwacji tych wypływa wniosek, że struktura przestrzenna gospodarczych funkcji kontrolnych w aspekcie podległości podmiotów rynkowych dowiązuje do popytu demograficznego. Niewątpliwie konkluzja ta ma charakter wstępny, a potwierdzenie tego wymaga bardziej pogłębionych studiów.

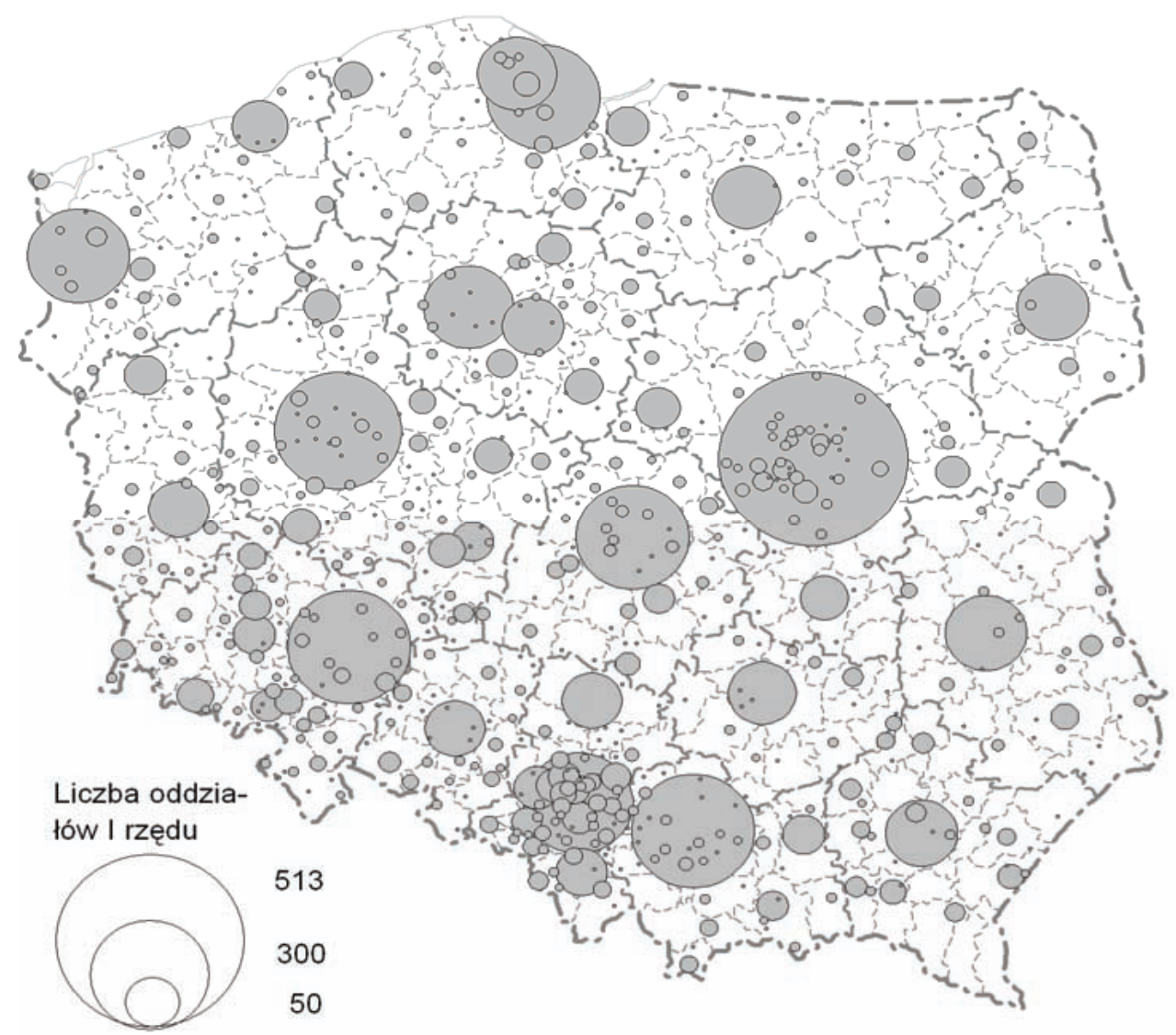

Ryc. 1. Rozmieszczenie oddziałów I rzędu 2 tys. największych przedsiębiorstw w Polsce (2006 r.)

Źródło: Opracowanie własne

W zakresie kierunków powiązań organizacyjnych obserwowana struktura jest pochodną koncentracji dużej liczby central przedsiębiorstw zlokalizowanych w Warszawie (ryc. 3). Zidentyfikowano następujące liczby powiązań pomiędzy centralami w stolicy a oddziałami pierwszego rzędu: z Krakowem (136), Poznaniem (129), Wrocławiem (121), Łodzią (108), Katowicami (102), Gdańskiem (89), Szczecinem (81), Bydgoszczą (71), Lublinem (58) i Białymstokiem (51). Natomiast jeśli zestawić je w kolejności, to okaże się, że powiąza- 
nia niewychodzące ze stolicy znajdują się dopiero na miejscu 17 (Kraków-Warszawa - 30) i 20 (Poznań-Warszawa-25).

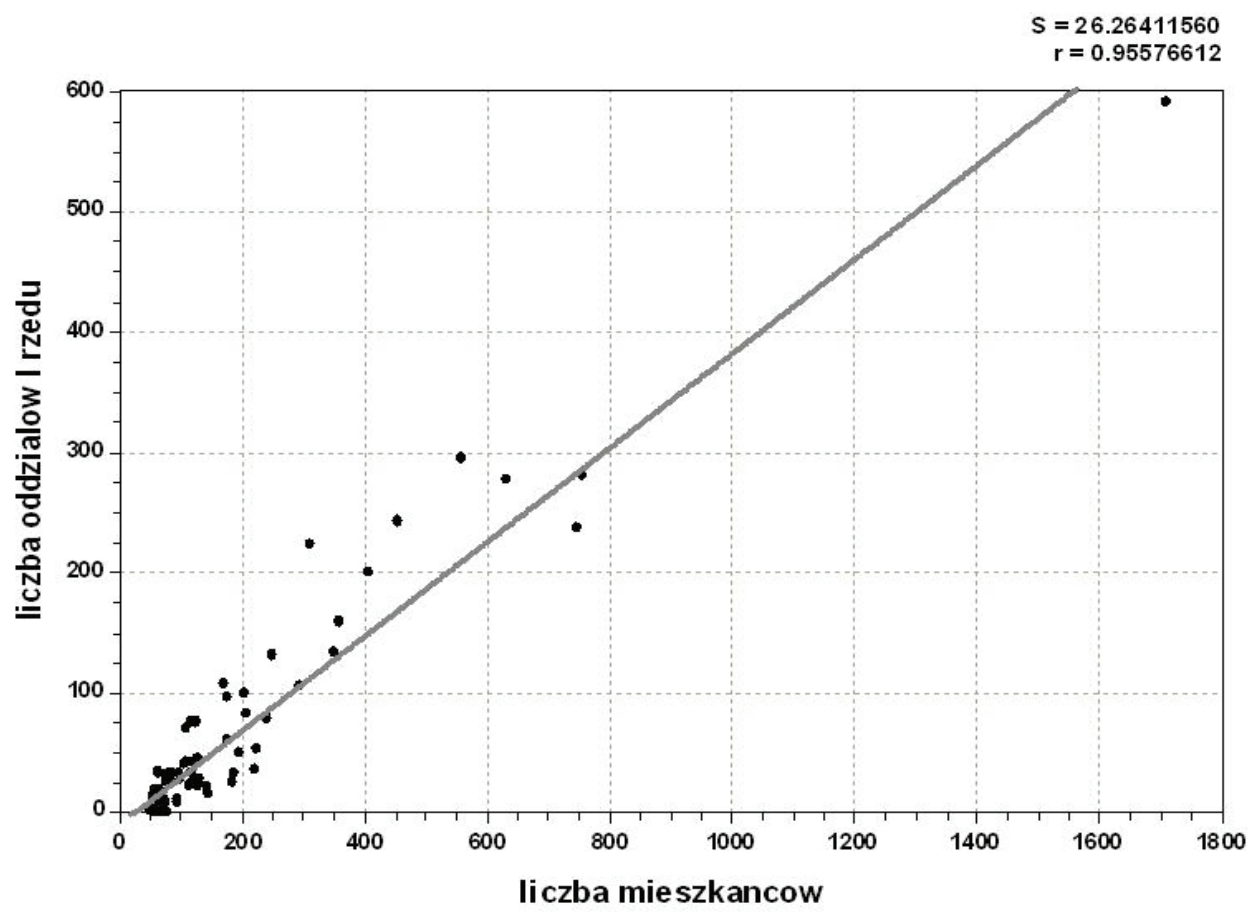

Ryc. 2. Regresja liniowa pomiędzy liczbą ludności miast powyżej 50 tys. mieszkańców a liczbą oddziałów (2006 r.)

Źródło: Opracowanie własne

Generalnie, występujący układ powiązań organizacyjnych można uznać za hierarchiczny, a dalej niezrównoważony i biegunowy. Uwidacznia się w tym przypadku jednak stosunkowo duża rola miast wojewódzkich drugiego rzędu, tj. niemetropolitalnych, na przykład Opola, Zielonej Góry, Olsztyna, jak również dużych ośrodków niewojewódzkich (Radom, Częstochowa oraz - co charakterystyczne - Koszalina). Nie obserwuje się tutaj dominacji powiązań tylko z ośrodkami największymi, tak jak to dalej będzie wykazane w przypadku powiązań właścicielskich. Zatem w tym przypadku można stawiać ostrożną tezę, że struktura powiązań nie tylko dostosowuje się do podziału administracyjnego, ale też że podnosi rangę niektórych ośrodków.

Inną cechą powiązań organizacyjnych przedsiębiorstw zlokalizowanych w Polsce jest ich skupienie się na rynku wewnętrznym. Badania wykazały, że na 11,7 tys. oddziałów pierwszego rzędu tylko około 200 znajduje się za granicą. Najwięcej z nich było w Niemczech (53, z czego 7 w Hamburgu oraz po 5 w Kolonii i Berlinie), następnie w Rosji (37, z czego 11 w Moskwie), 27 w Czechach (9 w Pradze) oraz 10 na Litwie (9 w Wilnie). W innych krajach przypadki lokalizowania oddziałów były jeszcze bardziej sporadyczne. 


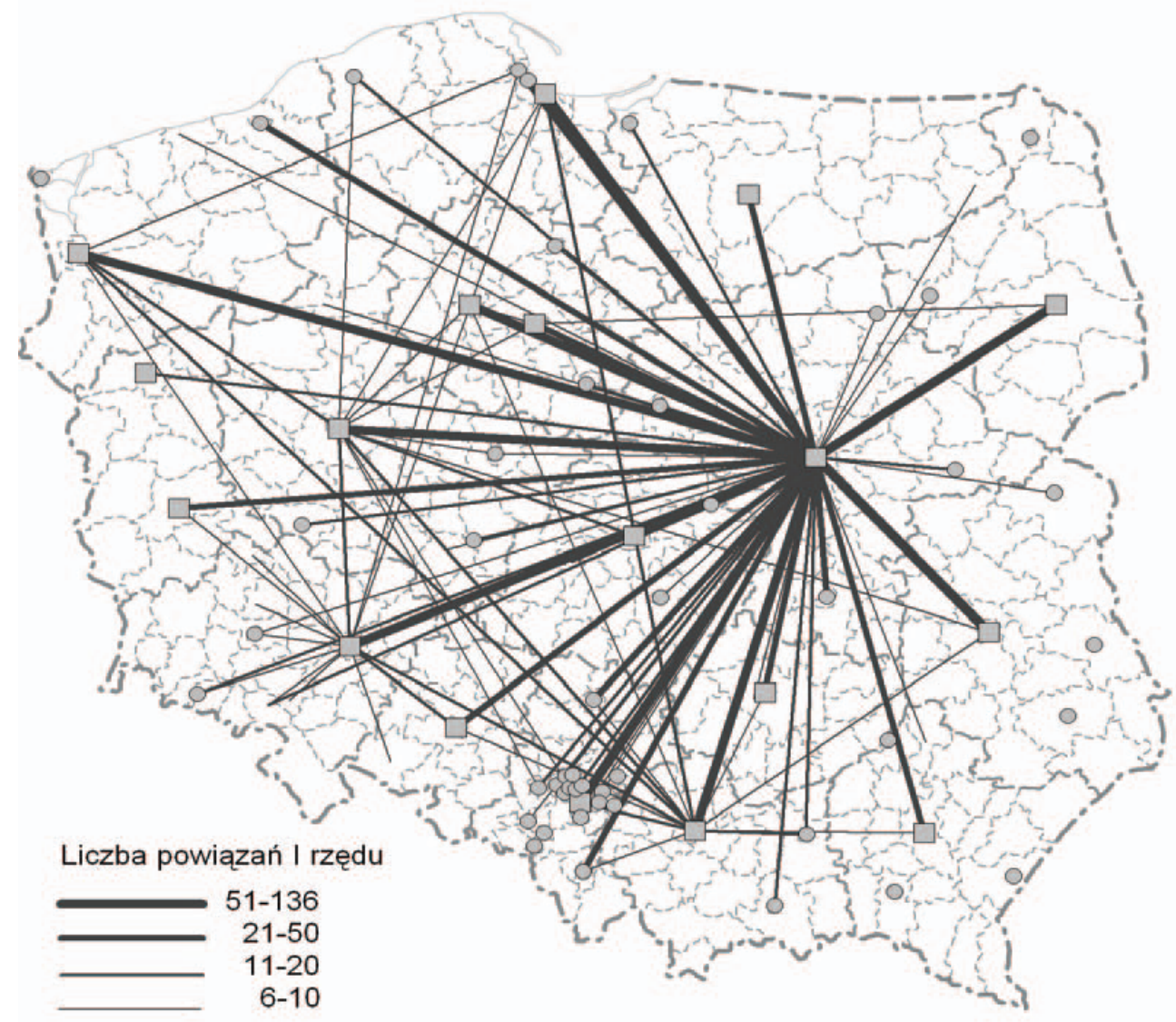

Ryc. 3. Kierunki powiązań organizacyjnych central i oddziałów I rzędu 2 tys. największych przedsiębiorstw w Polsce (2006 r.). Wyłączono powiązania w obrębie tych samych miast i gmin

Źródło: Opracowanie własne

\section{PowiAZZANIA WŁAŚCICIELSKIE}

Powiązania właścicielskie szczegółowo omówiono w innej pozycji (Śleszyński 2007), dlatego też w tym miejscu przedstawiono tylko najważniejsze kwestie. W układzie międzynarodowym główne kierunki ciążeń przebiegają w układzie równoleżnikowym i obserwowane jest silne uzależnienie od środków dyspozycyjnych w Europie Zachodniej. Następnie Warszawa jest „hubem” powiązań właścicielskich, przez co cały układ powiązań ma quasi-hierarchiczny charakter. W modelu tym stolica jest pośrednikiem (albo też trzonem lub hubem) powiązań, akumulując przychodzące z zagranicy powiązania właścicielskie, a następnie kontrolując firmy zlokalizowane wewnątrz swego obszaru metropolitalnego i w całej Polsce. Układ ten jest dominujący, typowy dla większości rodzajów działalności 
przemysłowych i usługowych. W niektórych zaawansowanych działalnościach powiązania właścicielskie kończą się na wyższych stopniach administracyjno-osadniczych, gdyż niżej nie ma zlokalizowanych firm danej specjalności. Charakterystyczne jest też słabe znaczenie pozostałych ośrodków osadniczych (ryc. 4). Wyraźne jest również ,pęknięcie” układów powiązań właścicielskich, polegające na tym, że ośrodki administracyjno-osadnicze niższego szczebla w większym stopniu są kontrolowane przez przedsiębiorstwa umiejscowione za granicą, niż ośrodki położone na wyższych szczeblach hierarchicznych w kraju.

Równocześnie powiązania właścicielskie w kierunku odwrotnym zdarzały się niezwykle rzadko i dotyczyły firm o różnym przekroju branżowym. W sumie bilans przepływów właścicielskich był zdecydowanie korzystny dla Warszawy. Saldo powiązań przychodzących i wychodzących było ujemne we wszystkich kategoriach administracyjno-osadniczych. W Warszawie wyniosło ono $320 \mathrm{mld}$ zł, a w pozostałych ośrodkach metropolitalnych 240 mld zł. Strukturę tych zależności zestawiono w tabeli 1 i 2.

W działalności handlowej, a w mniejszym stopniu przemysłowej, dostrzec można pewne cechy hierarchiczności. W roku 2004 polegała ona na częstszym i silniejszym, zarówno w wartościach bezwzględnych, jak i procentowych, udziale kontroli przychodów wśród ośrodków położonych bliżej siebie pod względem kategorii administracyjno-osadniczej. Warto zwrócić uwage na silne powiązania zagraniczne, które wychodziły z tradycyjnie dobrze rozwiniętych obszarów Europy Zachodniej oraz Stanów Zjednoczonych.

O ile w stosunku do struktury powiązań organizacyjnych można ostrożnie formułować wniosek o zrównoważonym charakterze w stosunku do struktury administracyjno-osadniczej (przy silnej nadreprezentacji Warszawy w zakresie koncentracji central), to sieć powiązań kapitałowych wykazuje znacznie wyraźniejsze tendencje do polaryzacji przestrzennej.

Tab. 1. Kontrola właścicielska firm zlokalizowanych w Polsce w wartościach bezwzględnych (2004/2005)

\begin{tabular}{|l|r|r|r|r|r|r|r|r|}
\hline \multirow{2}{*}{ Kontrola wychodząca z ośrodków } & \multicolumn{7}{|c|}{ Kontrola przychodzaca do ośrodków } \\
\cline { 2 - 9 } & \multicolumn{1}{|c|}{1} & 2 & 3 & 4 & 5 & 6 & Razem \\
\cline { 2 - 9 } & \multicolumn{7}{|c|}{ w \% } \\
\hline z zagranicy & 30,1 & 16,4 & 1,6 & 7,8 & 5,5 & 1,2 & 62,7 \\
ze stolicy* & 15,8 & 8,6 & 1,3 & 2,0 & 1,6 & 0,3 & 29,6 \\
z pozostałych metropolitalnych*,** & 0,4 & 1,4 & 0,4 & 0,2 & 0,6 & 0,2 & 3,3 \\
z pozostałych wojewódzkich* & 0,2 & 0,1 & 0,3 & 0,1 & 0,1 & & 0,7 \\
z pozostałych grodzkich* & 0,4 & 0,4 & $<0,1$ & 1,0 & $<0,1$ & $<0,1$ & 1,9 \\
z pozostałych powiatowych & 0,4 & 0,2 & 0,1 & 0,1 & 0,6 & $<0,1$ & 1,4 \\
z pozostałych (małe miasta i obszary wiejskie) & 0,1 & 0,1 & $<0,1$ & & $<0,1$ & $<0,1$ & 0,4 \\
\hline Razem & 47,4 & 27,2 & 3,7 & 11,3 & 8,5 & 2,0 & 100,0 \\
\hline
\end{tabular}

* obszary metropolitalne, ** Kraków, Katowice, Wrocław, Poznań, Łódź, Gdańsk i Szczecin Źródło: Śleszyński 2007, uproszczone 
Tab. 2. Struktura geograficzna kontroli właścicielskiej przedsiębiorstw (2004/2005)

\begin{tabular}{|c|c|c|c|c|c|}
\hline \multirow{3}{*}{ Nazwa } & \multirow{2}{*}{$\begin{array}{c}\text { Wartość } \\
\text { PKB }\end{array}$} & \multicolumn{4}{|c|}{$\begin{array}{l}\text { Wartość kontrolowanych przychodów największych przedsię } \\
\text { biorstw (wraz z kontrolą wewnętrzną w obrębie jednostek) }\end{array}$} \\
\hline & & wychodzące & przychodzące & saldo & $\begin{array}{l}\text { saldo jako } \\
\text { relacja } \\
\text { do PKB* }\end{array}$ \\
\hline & \multicolumn{4}{|c|}{ mld zł } & $\%$ \\
\hline \multicolumn{6}{|c|}{ Polska } \\
\hline Ogółem & 922,9 & 323,6 & 875,8 & $-551,8$ & $-59,8$ \\
\hline \multicolumn{6}{|c|}{ Województwa } \\
\hline dolnośląskie & 71,3 & 6,1 & 48,0 & $-41,9$ & $-58,8$ \\
\hline kujawsko-pomorskie & 44,7 & 2,6 & 13,3 & $-10,7$ & $-23,9$ \\
\hline lubelskie & 36,7 & 1,4 & 10,6 & $-9,1$ & $-24,8$ \\
\hline lubuskie & 21,8 & 0,2 & 5,2 & $-5,0$ & $-22,9$ \\
\hline łódzkie & 57,7 & 9,8 & 25,5 & $-15,7$ & $-27,2$ \\
\hline małopolskie & 67,3 & 5,0 & 52,6 & $-47,6$ & $-70,7$ \\
\hline mazowieckie & 188,3 & 269,2 & 475,8 & $-206,6$ & $-109,7$ \\
\hline opolskie & 21,9 & 1,1 & 6,9 & $-5,8$ & $-26,5$ \\
\hline podkarpackie & 35,4 & 0,9 & 10,6 & $-9,7$ & $-27,4$ \\
\hline podlaskie & 21,7 & 1,4 & 4,8 & $-3,3$ & $-15,2$ \\
\hline pomorskie & 51,8 & 2,7 & 30,1 & $-27,4$ & $-52,9$ \\
\hline śląskie & 127,9 & 13,7 & 98,6 & $-84,8$ & $-66,3$ \\
\hline świętokrzyskie & 24,1 & 2,4 & 9,6 & $-7,1$ & $-29,5$ \\
\hline warmińsko-mazurskie & 26,8 & 1,5 & 5,3 & $-3,8$ & $-14,2$ \\
\hline wielkopolskie & 87,4 & 5,3 & 69,0 & $-63,7$ & $-72,9$ \\
\hline zachodniopomorskie & 38,1 & 0,3 & 9,9 & $-9,6$ & $-25,2$ \\
\hline \multicolumn{6}{|c|}{ Wybrane obszary metropolitalne } \\
\hline Kraków & 28,4 & 3,5 & 44,2 & $-40,8$ & $-143,7$ \\
\hline Łódź & 22,6 & 9,3 & 16,1 & $-6,8$ & $-30,1$ \\
\hline Poznań & 28,1 & 2,7 & 46,9 & $-44,2$ & $-157,3$ \\
\hline Trójmiasto & 26,2 & 2,7 & 21,4 & $-18,7$ & $-71,4$ \\
\hline Warszawa & 115,2 & 260,8 & 398,3 & $-137,5$ & $-119,4$ \\
\hline Wrocław & 21,9 & 2,1 & 20,8 & $-18,7$ & $-85,4$ \\
\hline
\end{tabular}

* wartość wskaźnika nie obrazuje udziału w PKB

Źródło: Śleszyński 2008a, uzupełnione 


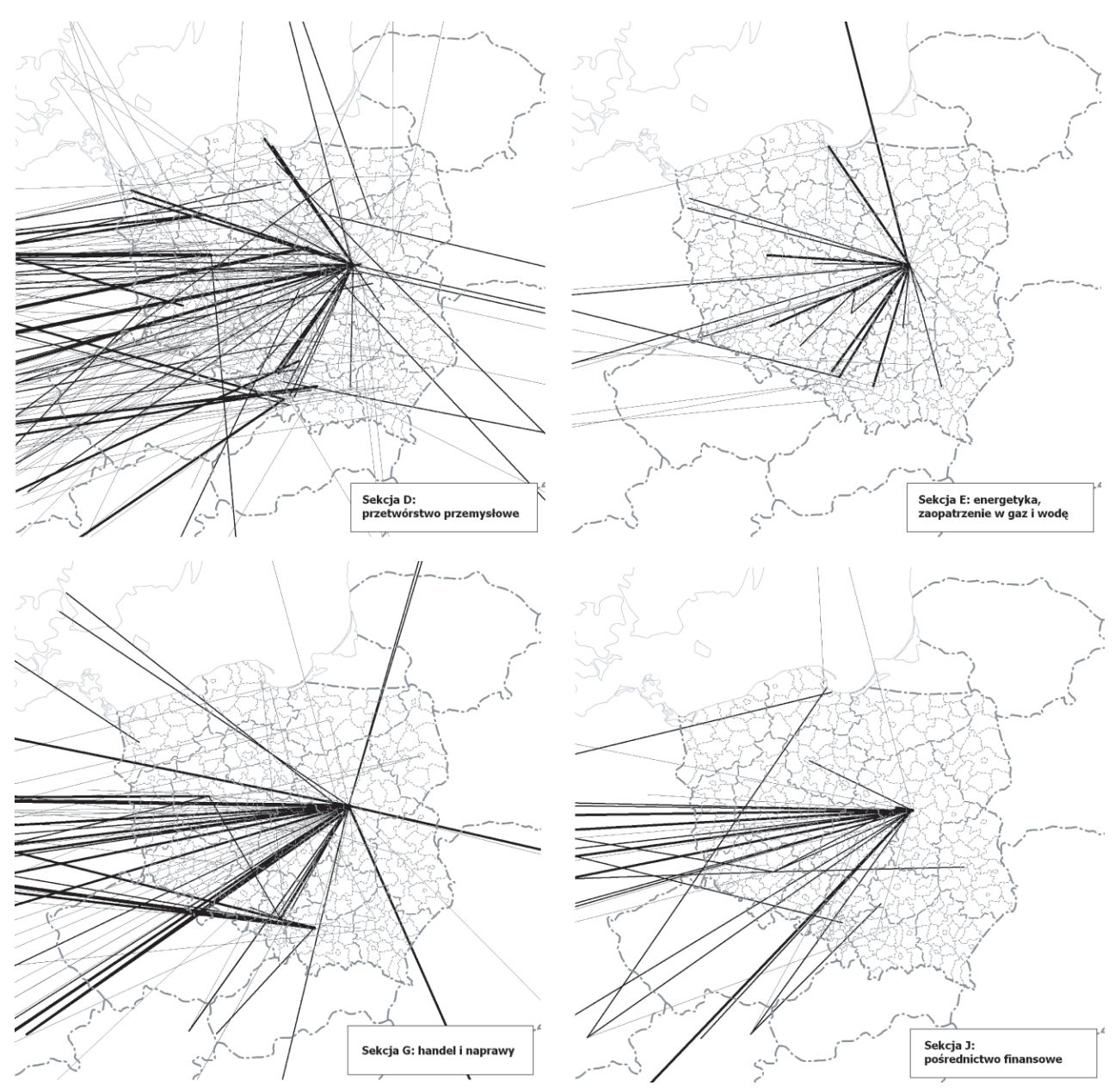

Ryc. 4. Siła i kierunki powiązań właścicielskich największych przedsiębiorstw w Polsce według wybranych sekcji PKD (2004/2005). Zaznaczono powiązania o sile $300 \mathrm{mln}$ zł i więcej

Źródło: Opracowanie własne

\section{Powiązania GosPodARCZE W MODELU CENTRUM-PERYFERIE}

Przeprowadzona analiza powiązań właścicielskich dostarczyła przesłanek do budowy modeli związanych z przestrzenną współzależnością ośrodków zarządzania. Jak wykazano, gospodarcze funkcje kontrolne w Polsce charakteryzują się bardzo dużym związaniem z ośrodkami położonymi za granica, przy czym współzależność ta ma charakter wybitnie jednokierunkowy. Można zatem formułować tezę o podległości gospodarczej, związanej z kontrolą polskich ośrodków zarządzania przez ośrodki zagraniczne. Stąd też niejako naturalne wydaje się w dalszej kolejności zastosowanie modelu centrum-peryferie (rdzeń-peryferie). Idea ta jest znana w ekonomii, politologii (geopolityce) i geografii co najmniej od końca XIX wieku i wykorzystywana była później m.in. do budowy teorii dominacji 
gospodarczej. Zarówno w geografii ekonomicznej, jak i ekonomii przestrzennej w odniesieniu do organizacji przestrzennej znalazła bardzo duże zainteresowanie. Szczególnie szerokim echem odbiła się praca J. Friedmanna (1967), którego uważa się obecnie za twórcę współczesnej koncepcji centrum-peryferie. Model centrum-peryferie zasadza się na założeniu, że istnieje zasadnicze zróżnicowanie pomiędzy dwoma regionami, spośród których jeden posiada wyższy stopień rozwoju (centrum). W wyniku przewagi wynikającej z posiadania i kontroli przepływów dóbr, kapitału, informacji itd. następuje podporządkowanie obszaru (obszarów) o niższym stopniu rozwoju (peryferie).

Istotą modelu centrum-peryferie są zatem relacje władzy i podległości. Dlatego też bardzo dobrze nadają się do tłumaczenia relacji własności i powiązań gospodarczych. Przyjmijmy na początek, że relacje pomiędzy dwoma regionami, w przypadku ich wystąpienia, mogą być dwojakiego rodzaju: równoprawnego i zależnego oraz że skala przestrzenna może obejmować wszystkie powiązania lub ich część wydzieloną na podstawie jakichś kryteriów.

Przeprowadzone analizy skłaniają do przyjęcia następujących zaobserwowanych prawidłowości w kontekście modelu centrum-peryferie:

1) w układzie międzynarodowym:

a) ośrodki zarządzania gospodarczego położone na obszarze Polski są podległe w układzie: kraj - wysoko rozwinięte państwa Europy Zachodniej oraz (uzupełniająco) Stany Zjednoczone;

b) główne ośrodki kontroli zagranicznej skoncentrowane są na kilku niewielkich przestrzennie obszarach, związanych $\mathrm{w}$ ponad połowie $\mathrm{z}$ dobrze rozwiniętymi największymi aglomeracjami, w tym tzw. miastami światowymi (globalnymi);

c) istnieje duża selektywność pod względem wyboru aglomeracji kontrolujących polskie ośrodki, generalnie odzwierciedlają one jednak strukturę zarządzania gospodarczego w krajach-właścicielach. W Europie są to przede wszystkim Amsterdam, Paryż i Londyn, w Stanach Zjednoczonych - Nowy Jork;

d) w Polsce rolę głównego miejsca kontaktu i pośrednika dla dalszych powiązań pełni ośrodek stołeczny;

2) w układzie krajowym:

a) rolę centrum pełni ośrodek stołeczny, ma on silną pozycję dominującą nad całym pozostałym obszarem;

b) semiperyferiami są pozostałe ośrodki metropolitalne, głównie trójmiejski, poznański, wrocławski, katowicki i krakowski, a także niektóre miasta powiatowe (Płock, Lubin, Jastrzębie Zdrój);

c) pozostałe obszary pełnią rolę peryferii i są całkowicie uzależnione, przede wszystkim od stolicy i zagranicznych ośrodków kontroli, a w mniejszym stopniu od innych obszarów metropolitalnych. Trzeba w tym miejscu podkreślić, że prawidłowość ta dotyczy jednak tylko dużych przedsiębiorstw, będących przedmiotem analizy. W miarę spadku rangi administracyjnej coraz większą rolę pełnią mniejsze jednostki. W najmniejszych ośrodkach małe i średnie firmy są często jedynymi podmiotami gospodarczymi.

Ponadto wyraźne jest „pęknięcie” układów powiązań właścicielskich, polegające na tym, że ośrodki administracyjno-osadnicze niższego szczebla w większym stopniu są kontrolowane przez przedsiębiorstwa umiejscowione za granica, niż ośrodki położone na wyższych szczeblach hierarchicznych w kraju. To rozerwanie istniejącej hierarchii gospodarczej dodatkowo potwierdza koncepcję podległości. Równocześnie w układzie międzynarodowym powiąza- 
nia ekonomiczne mają w większym stopniu charakter sieciowy, a w krajowym - biegunowy (oparty na Warszawie). Jeśli połączymy obydwa zaobserwowane rodzaje relacji, uzyskamy układ zależności, który w pewien sposób przypomina jednak hierarchię (układ quasi-hierarchiczny; ryc. 5). Taki charakter powiązań wynika z faktu, że gospodarka w krajach wysoko rozwiniętych funkcjonuje w dużym stopniu w układzie sieciowym, a Polska do tego modelu dopiero się dostosowuje. Tym niemniej, jeśli zwrócimy uwagę na skalę przestrzenną tych relacji i uwzględnimy istotę zależności w modelu centrum-peryferie, przedstawiony model (ryc. 5) będzie utrzymywał się tak długo, jak długo Polska będzie pozostawała obszarem peryferyjnym.
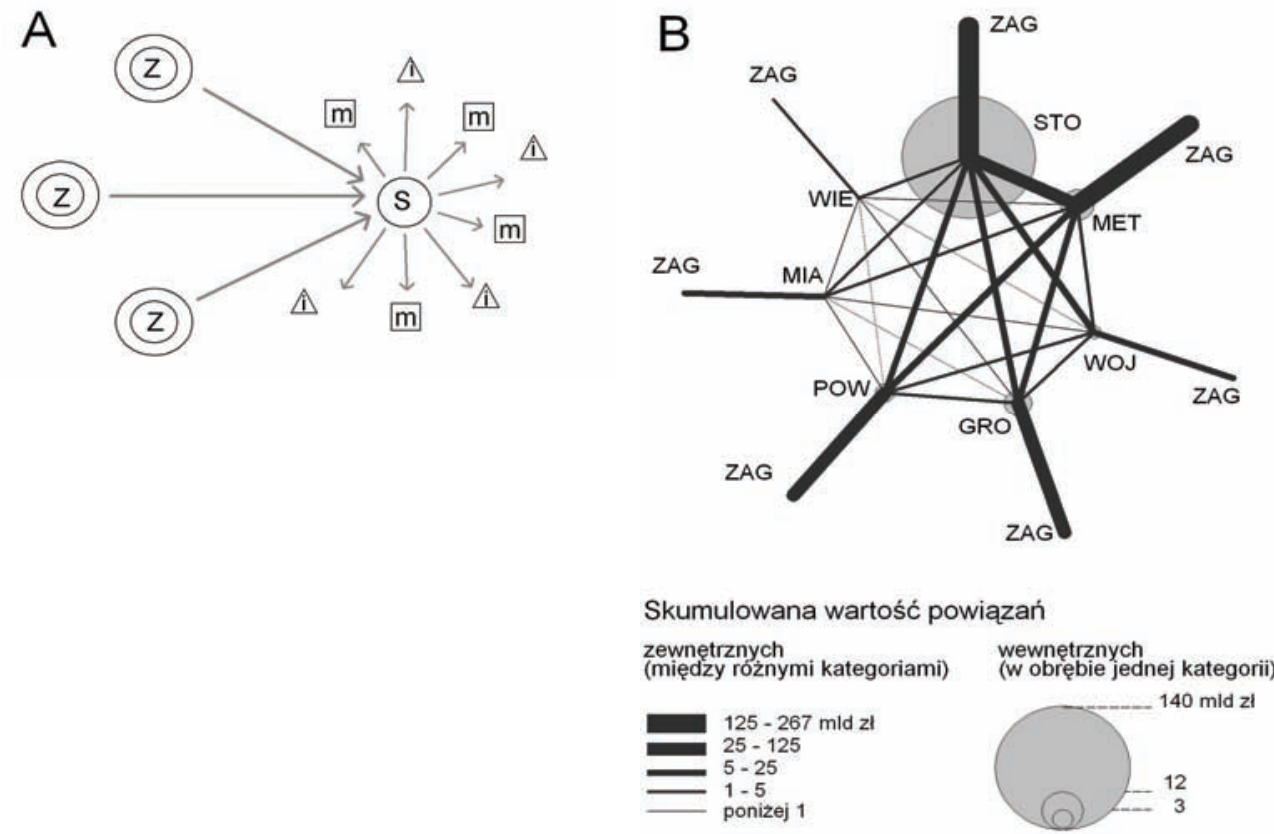

Ryc. 5. Modele powiązań właścicielskich przedsiębiorstw w Polsce

A - Uogólniony model quasi-hierarchiczny. Ośrodki: Z - zagraniczne; S - stołeczny (hub); m - inne metropolitalne; i - inne

B - Struktura powiązań zagregowana do 7 kategorii ośrodków. Kategorie: ZAG - zagranica, STO - stolica (Warszawa), MET - pozostałe ośrodki metropolitalne (tzw. MEGA), WOJ - pozostałe ośrodki wojewódzkie, GRO - pozostałe ośrodki powiatowe grodzkie, POW - pozostałe miasta powiatowe, MIA - pozostałe miasta, WIE - pozostałe miejscowości

Źródło: Śleszyński 2007

\section{DYSKUSJA I WNIOSKI DLA POLITYKI REGIONALNEJ}

W ciągu ostatniego dwudziestolecia zmianie uległy niemal wszystkie ważniejsze ramy prawno-organizacyjne, warunkujące rozwój instytucjonalny podmiotów gospodarczych. W wyniku rozpadu dotychczasowych struktur powstała nowa organizacja przestrzenna 
zarządzania gospodarczego. Równoczesny napływ kapitału zagranicznego spowodował „wprzęgnięcie” rodzimych podmiotów do europejskich i światowych powiązań gospodarczych. Przejęcie kontroli właścicielskiej nad znaczną częścią przychodów przedsiębiorstw spowodowało, że wprawdzie pozycja Warszawy jako głównego ośrodka dyspozycyjnego w kraju została zachowana (lub też niekiedy nawet wzmocniona), ale zmieniła się jej pozycja względem innych centrów decyzyjnych zlokalizowanych poza granicami państwa. Wskutek inwestycji kapitałowych nastąpiło rozerwanie systemu krajowego na rzecz powiązań i relacji międzynarodowych.

Równocześnie powstawanie nowej organizacji przestrzennej zarządzania gospodarczego ma charakter dostosowania się do istniejących struktur zarządzania, usytuowanych głównie w Warszawie. Wynika to z inercji przestrzennej oraz dużego oporu w zmianach struktury społeczno-gospodarczej ośrodków administracyjno-osadniczych, w tym znacznej przewagi Warszawy jako miejsca skupienia władzy publicznej i dotychczas wykształconych sieci powiązań biznesowych, umożliwiających łatwiejszy dostęp do informacji, instytucji, polityków, specjalistycznej kadry itd. W efekcie tego następuje koncentracja gospodarczych funkcji kontrolnych. Rezultatem zmian jest utrzymywanie się lub pogłębianie struktury monocentrycznej całego układu, a tym samym polaryzacja gospodarcza. Z punktu widzenia rozwoju regionalnego w układzie krajowym jest to proces negatywny.

Dla dalszego wywodu warto też przytoczyć identyfikację następujących ról wynikających z istnienia gospodarczej funkcji kontrolnej w danej miejscowości (Śleszyński 2002):

1) rola gospodarcza: udział w tworzeniu miejscowego PKB i odprowadzaniu podatków, w zależności od posiadania (lub nie) oddziałów zamiejscowych, efekty mnożnikowe (vide wspomniana reakcja prezydenta Lublina po umiejscowieniu siedziby BOT w 2006 r.);

2) rola społeczna: a) wynikająca z aspektów gospodarczych (np. wpływ na stopę bezrobocia, migracje związane z przyciaganiem wysoko kwalifikowanej kadry) oraz b) polegająca na kreowaniu wizerunku poprzez podnoszenie prestiżu miejscowości i regionu;

3) rola polityczna: udział lub wpływy przedstawicieli biznesu na władze lokalne i tym samym realny wpływ przedsiębiorstwa na administrację lokalną oraz zarządzanie miejscowością i regionem (o powiązaniach funkcji zarządczych biznesu i polityki na przykładzie spółek węglowych oraz generalnie o klientelizmie politycznym przekonująco pisała m.in. Gadowska 2003).

Wymienione przesłanki stały się punktem wyjścia w pracach związanych z oceną powiązań gospodarczych i kapitałowych pomiędzy miastami dla potrzeb nowej Koncepcji Przestrzennego Zagospodarowania Kraju (Śleszyński 2008b). Wykazana zasadnicza niezgodność funkcji decyzyjno-kontrolnych w stosunku do rozmieszczenia sił wytwórczych i zasobów ludnościowych wskazuje bowiem na nierównowagę systemową. Nie chodzi przy tym o kolejność w strukturze pomiędzy poszczególnymi stopniami administracyjno-osadniczymi, które w przypadku każdej struktury zarządzania muszą być zhierarchizowane. Istotne są tutaj odległości pomiędzy tymi szczeblami, mierzone wielkością kontrolowanego pieniądza w obiegu. W wymienionych pracach aplikacyjnych wskazywano, że superdominująca pozycja Warszawy ,przytłacza” pozostałe ośrodki, co może prowadzić do zachwiania równowagi pod względem gospodarczym w ukształtowanym policentrycznym systemie osadniczym.

Pryncypia gospodarki wolnorynkowej i coraz bardziej malejący w niej udział państwa z zasady ograniczają możliwości aktywnej publicznej polityki regionalnej w zakresie decentralizacji gospodarczych funkcji kontrolnych. Jedynym rozsądnym działaniem wydaje się lo- 
kalizowanie siedzib dużych spółek, pozostających w rękach Skarbu Państwa poza Warszawą. Przykład takiego działania miał miejsce w 2004 r. i było to umiejscowienie w Łodzi siedziby koncernu BOT Górnictwo i Energetyka, powstałej w 2004 roku z kopalń i elektrowni w Bełchatowie, Opolu i Turowie. Z kolei wiosną 2007 r., w wyniku dalszej konsolidacji przedsiębiorstw tej branży, powstała największa w Polsce spółka Polska Grupa Energetyczna. Jej centralę z kolei umiejscowiono w Lublinie. Andrzej Pruszkowski, prezydent tego miasta, decyzję tę skomentował wcześniej w następujący sposób: „Jestem najprawdopodobniej jednym z najszczęśliwszych ludzi w Polsce. Prawdopodobnie od kilkudziesięciu lat nie padła tak ważna dla Lublina i regionu lubelskiego informacja" (według informacji prasowych z dn. 23.10.2006 roku). Świadczy to dobitnie, jaką rolę przywiązuje się do lokalizacji siedzib dużych firm i ich znaczenia dla lokalnego i regionalnego rozwoju.

W nawiązaniu do powyższych wniosków, na podstawie nowszych wyników badań prezentowanych również w niniejszym artykule, można dodawać istotne uzupełnienia. W stosunku do powiązań kapitałowych, znacznie korzystniej wygląda sytuacja w zakresie lokalizacji oddziałów największych przedsiębiorstw. W tym przypadku występuje bardzo duża zgodność w stosunku do potencjału demograficznego. Należy to interpretować niewątpliwie jako czynnik łagodzący przerost gospodarczych funkcji kontrolnych w ośrodku stołecznym. Równocześnie jest to czynnik sprzyjający dostępności do usług wyższego rzędu i porządkujący gospodarcze struktury regionalne zgodnie z obowiązującym podziałem administracyjno-terytorialnym.

\section{Literatura}

Eberhardt P., 1986, Rejonizacja przedsiębiorstw zaopatrzenia, dystrybucji $i$ handlu hurtowego $w$ Polsce, Przegląd Geograficzny, 58, 4, s. 703-733

Friedmann J., 1967, A general theory of polarized development, Ford Foundation, Urban and Regional Development Advisory Program in Chile, Santo Domingo

Gadowska K., 2003, Zjawisko klientelizmu polityczno-ekonomicznego. Systemowa analiza powiqzań sieciowych na przyktadzie przeksztatceń sektora górniczego w Polsce, Wydawnictwo UJ, Kraków

Garrison W.L., 1959-1960, The Spatial structure of the economy, Annals of the Association of the American Geographers, I, II, III, 49, s. 238-248, 471-482, 50, s. 357-373

Kerr D., 1965, Some aspects of the geography of finance in Canada, Canadian Geographer, 6, 4, s. 175-192

Śleszyński P., 2008a, Duże przedsiębiorstwa w strukturze przestrzennej największych polskich miast, Prace Geograficzne, 217, Instytut Geografii i Przestrzennego Zagospodarowania PAN, Warszawa

Śleszyński P., 2008b, Ocena powiazań gospodarczych i kapitałowych między miastami, [w:] K. Saganowski, M. Zagrzejewska-Fiedorowicz, P. Żuber (red.), Ekspertyzy do Koncepcji Przestrzennego Zagospodarowania Kraju 2008-2033. Tom I, Ministerstwo Rozwoju Regionalnego, Warszawa, s. 335-391

Śleszyński P., 2007, Gospodarcze funkcje kontrolne w przestrzeni Polski, Prace Geograficzne, 213, Instytut Geografii i Przestrzennego Zagospodarowania PAN, Warszawa

Śleszyński P., 2002, Struktura i rozmieszczenie ośrodków zarzadzania w polskiej gospodarce $w 2000$ r., Przegląd Geograficzny, 65, 2, s. 199-228

Wheeler J.O., 1988, Spatial ownership links of major corporations: The Dallas and Pittsburgh examples, Economic Geography, 64, 1, s. 1-16 


\section{Organizational and ownership linkages of industrial and service enterprises in Poland, and their significance for regional development}

The article presents a study concerning the development of the network of ownership linkages for the Polish enterprises operating in the industrial and services sector. The analysis covered 1,200 largest enterprises operating in Poland in 2005, and for the purpose of the study the comprehensive data concerning the shareholding structure of those business entities - including details such as ownership, property and geography - were collected. The research indicates that there is a concentration of economic control function in the higher levels of the settlement hierarchy, which results in maintaining or even deepening the monocentric structure of the entire system, thus strengthening the process of economic polarization. From the point of view of regional development viewed in the light of national context this is a negative process. However, a much more beneficial situation is developing in regard to choosing the location for the local branches of major enterprises, where it can be asserted that the arrangements in this respect are well harmonized with the existing demographic potential. This fact must be perceived as a factor alleviating the excess of economic control function that is evident in the capital city of Warsaw. Also, at the same time this is an element that enhances accessibility to the highly-specialized services, as well as organization of economic regional structures in accordance with the current administrative-territorial division.

Dr hab. Przemysław Śleszyński

Instytut Geografii i Przestrzennego Zagospodarowania PAN

Warszawa

e-mail: psleszyn@twarda.pan.pl 